\title{
LONG-RUN OPERATING PERFORMANCE OF QUALITY CERTIFIED FIRMS
}

\author{
Eurico Ferreira, Indiana State University \\ Eli Kofi Aba, Indiana Sate University
}

dx.doi.org/10.18374/JIFS-13-3.16

\begin{abstract}
With a large number of US firms, obtaining the ISO 9000 quality certification, we investigate the impact of the certification on those firms' operating performance. The data used in this study is from the ISO 9000 Registered Company Directory - North America CD published by the McGraw-Hill Company, and includes 397 firms in 36 industries. Our results indicate the most benefits occur before certification.
\end{abstract}

Keywords: ISO9000 quality certification, Industry-adjusted and matched-adjusted operating performance, and control firms. JEL classification: G32, G33, G34 